\title{
Relationship Between Child-Mother Secure Attachment Style and Violence in Adolescent Romantic Relationship
}

\author{
Zarra Janna Mubammad'; Yulia Ayriza ${ }^{1}$ \\ ${ }^{1}$ Department of Psychology, Universitas Negeri Yogyakarta, \\ Jl. Colombo No. Depok, Sleman, Yogyakarta 55281, Indonesia \\ zarra98janna@gmail.com
}

\begin{abstract}
This study aimed to assess the correlation between the secure attachment style of child-mother and violence in adolescents' romantic relationships. A quantitative approach with a correlational method is used in this research. The subject in this study were 408 adolescents aged 18-22 years who were in romantic relationships and lives in the Special Region of Yogyakarta. The data collection method used in this study is the questionnaire method with the instrument used are the IPVAS-R scale and IPPA-M scale. Both scales used convergent validity with correlations of 0,18 0,78 . Then the two scales were re-validated by expert judgement. Reliability for the IPVAS-R was 0,76 , and the IPPA-M was 0,87 . The data analysis used a non-parametric correlation test. The research results showed a negative correlation between child-mother secure attachment style and dating violence with $r=-0,221$ and $\alpha=0,000(p<0,01)$. The higher the secure attachment style between child and mother, the lower the violence in romantic relationships.
\end{abstract}

Keywords: attachment style; dating violence; adolescent

\section{Introduction}

According to Hurlock (1996, in Ardi, Ibrahim, \& Said, 2012: 1), adolescence's most challenging developmental task is related to social adjustment, one of which is adjusting relationships with peers of the opposite sex. Relationships with friends of the opposite sex can lead to an attraction that leads to romantic relationships or better known as courtship. According to Santrock (2012: 449), courtship is a form of recreation, status, a setting for studying close relationships, and also a way to find a partner.

According to Wolfe and Feiring (2000, in Trifiani \& Margaretha, 2012: 75), dating can support psychological development and provide many positive meanings (Connolly \& Johnson, 1996; Feiring, 1996; Gray \& Steinberg, 1999; Wolfe \& Mash, 2006 in Trifiani \& Margaretha, 2012: 75). Teenagers who have a partner can develop social cognition, namely the ability to understand others as unique in nature, interests, values , and feelings (Yusuf, 2011; Ardi, Ibrahim, \& Said, 2012: 2). The development of social cognition can certainly help adolescents achieve one of their developmental tasks, namely social adjustment. These benefits are obtained if the romantic relationship that exists has a positive and harmonious atmosphere. Building a harmonious relationship is very important so that the dating relationship that is lived can develop each other between partners. An excellent romantic relationship occurs when individuals can resolve conflicts due to existing differences, but not all individuals can accept differences and resolve conflicts efficiently.

Late adolescence has developmental characteristics in stable psychological and physical aspects, an increased level of realistic thinking and a good perspective, 
more maturity in dealing with problems, and increased emotional calm to master feelings (Gunarsa \& Gunarsa, 2001; Mappiare, 2000 in Putro, 2017: 29). This is very much needed in establishing a harmonious romantic relationship. However, not all late adolescents have the characteristics and developmental tasks they should. This, of course, will impact the people around them, including their partners, especially when faced with a problem. When a relationship is hit by conflict and cannot resolve properly, violence in romantic relationships can arise or violence in courtship.

Violence in romantic relationships, both verbal and non-verbal, is an attempt by one partner to control or dominate his partner, either sexually, psychologically, or physically, which can cause harm to his partner (Wolfe and Feiring, 2002 in Yuliani \& Fitria, 2017: 276). Cases of violence in dating (KDP) in Indonesia show a relatively high number. According to the 2019 Annual Records of Violence against Women by the National Commission on Violence against Women (Komnas Perempuan), there were 2,073 cases of KDP that occurred throughout 2018 in Indonesia. The Special Region of Yogyakarta also has a relatively high number of KDP cases. According to data listed on the website of an NGO engaged in the protection of women, the Rifka Annisa Women's Crisis Center Yogyakarta, 140 cases of domestic violence were handled from 2012 to 2017. In addition, cases of violence in dating in Yogyakarta mainly occurred in their late teens, aged 14-25, where there are 14 cases out of 32 cases.

One factor that influences violence in this romantic relationship is the history of violence in the family. The existence of violence in the family by parents or other family members will make children imitate it and can form an aggressive personality (Soeroso, 2010 in Adiswanisa \& Kristiana, 2012: 4; Purnama, 2016: 62). Therefore, it can be concluded that the interaction between parents and children in the family during childhood has an essential role in creating a positive personality. This will prevent children from committing violence in the future when interacting with people around them, including partners. The interaction that is formed between children and parents or caregivers is called attachment.

Attachment is an interaction based on a solid emotional bond between two individuals (Santrock, 2012: 219). Attachment is created since the individual is born from the mother's womb. Good experiences and interactions in early life with parents, especially mothers, have an essential role because children will develop an internal representation called an internal working model (Bowlby, 1988 in Pace, San Martini, \& Zavattini, 2011: 83). ). The internal work model contains expectations and strategies for regulating emotions, managing interpersonal relationships and exploratory behaviour, and dealing with conflict or challenging circumstances. This model also plays a role in the formation of the adhesive force. The attachment style itself is divided into two, namely, secure and insecure. The secure attachment style is where babies use caregivers as a safe base to explore their environment (Santrock, 2012: 221). Insecure attachment style is divided into two, namely avoidant and ambivalent. The avoidant attachment shows insecure attachment by avoiding behaviour from caregivers, and ambivalent attachment is often attached to the caregiver and then rejects it by pushing or kicking (Santrock, 2012: 221).

Attachment is a benchmark for future individual interactions because of the nature of continuous or continuous attachment. The child will be guided and apply the attachment style of the caregiver or his attached figure with the people around him, including his romantic relationship partner. The attachment style 
formed with the mother in the early stages of life will guide thinking, feeling, and behaving in romantic relationships (Hazan \& Shaver, 1994: 9). Children with a secure attachment style have good skills in managing interpersonal relationships, have emotional regulation skills, and can handle conflicts and difficult situations. When in a romantic relationship, he has the characteristics of a relationship that is full of happiness, trust, acceptance, has adaptive emotions, and compromises in solving problems (Hazan \& Shaver, 1987; Pistole, 1989 in Mayseless, 1991: 24; Cooper, Shaver, \& Collins, 1998: 1392). These things are necessary for establishing a good romantic relationship with a partner to avoid violence in romantic relationships. Therefore, it is essential to apply a safe attachment style between the child and mother from an early age to prevent violence in romantic relationships.

Several previous studies on secure attachment style and violence in romantic relationships still focused on attachment to parents, not explicitly measuring the attachment between child-mother or child-father. Research conducted by Sanjaya (2016) immediately combines both parents as attachment figures but does not explicitly distinguish how much attachment the child and mother have or the child and father. According to the researchers, this may lead to not knowing exactly which relationship is more strongly associated with violence in romantic relationships.

In addition, this study focuses on late adolescence, where the emotional, cognitive, and social aspects that are starting to mature are expected to establish romantic relationships without violence. However, the fact is that perpetrators of violent cases in romantic relationships in Yogyakarta are still dominated by late teens, causing a gap. Therefore, the researcher views it necessary to reexamine the relationship between violence in romantic relationships and secure attachment styles, focusing on attachment figures, namely mothers and late adolescent subjects. It is hoped that through this research, parents can apply a safe attachment style as a form of good parenting to children in order to prevent violence when establishing romantic relationships.

\section{Methods}

This study is a correlational research aiming to test the relationship between variables without manipulating variability (Azwar, 2018: 25).

\section{Research time and place}

The research was conducted since the proposal was made, starting from September 2019 to July 2020. The research was carried out in the Special Region of Yogyakarta by distributing online questionnaires through an online survey application (google form) from March to April 2020.

\section{Research Subject}

The population in this study are teenagers who live in the Special Region of Yogyakarta and are aged 18-22 years, which is late adolescence. The estimated number of the late adolescent population in the Special Region of Yogyakarta according to the projection data of the Central Statistics Agency (BPS) in 2020 is 289,870 people. Sampling using the type of sampling incidental or accidental sampling. The number of samples was determined by the Slovin formula and obtained a sample size of 399 . The data obtained by the researcher was 413 subjects, but five subjects filled out the scale with the same value from the beginning to the end of the statement. The five subjects were then eliminated, and the remaining 408 subjects could be analyzed. 


\section{Relationship Between Child-Mother Secure Attachment Style and Violence \\ Muhammad \& Ayriza}

Data Collection Techniques Research and Instruments

Data collection techniques in this study using the questionnaire method. The research was conducted by distributing online questionnaires with an online survey application (google form). There are two instruments used in this study. The scale of violence in romantic relationships uses the Intimate Partner Violence Attitude-Revised (IPVAS-R) by Fincham, Cui, Braithwaite, \& Pasley (2008), which was created by Smith, Thompson, Tomaka, \& Buchanan (2005). The IPVAS-R scale measures three aspects of violence in romantic relationships: abuse, violence, and control. The scale of safe attachment with mother uses the Inventory Parents and Peer Attachment-Mother Version (IPPA-M) developed by Armsden \& Greenberg (2009). This scale measures the dimensions of secure attachment, namely trust, communication, and alienation.

The IPVAS scale is 17 items, and the IPPA is 25 items, so the total items in this research instrument are 42 items. This research instrument includes items that are favourable and unfavourable. The number of favourable items is 31 items, and the number of unfavourable items is 11 items. Each scale includes aspects and dimensions of the two variables according to the existing theory. The form of the scale on the instrument used is five alternative answers. Alternative answers on the scale of violence in romantic relationships are very inappropriate (score one), not appropriate (score two), doubtful (score three), appropriate (score four), and very appropriate (score five). The attachment scale with the mother has alternative answers ranging from almost never or never correct (score one), rarely correct (score two), sometimes correct (score three), often correct (score four) and almost always or always correct (score 5).

\section{Validity and Reliability}

Instruments are valid if the measuring instrument used to obtain data (measure) can be used to measure what should be measured (Sugiyono, 2012: 121). Measurement of validity in this study uses content validity to assess the relevance of each statement to its purpose. It examines whether the overall content of the questionnaire is comprehensive following the information domain to be studied (Azwar, 2018: 149). Content validation is then consulted with an expert in the field of psychology.

The results of the total item test on the IPVAS-R scale contained three items (item numbers 2,16 , and 17 ) that did not meet the criteria $(r=0.20)$, so they had to be eliminated. After eliminating items that do not meet the criteria, the violence in romantic relationship scale has 14 items remaining with coefficients ranging from 0.22 to 0.58. Both instruments use convergent validity. Convergent validity showed that the control subscale scores on the IPVAS-R had a significant inverse correlation with the Pro-divorce Attitude scale $(r=-0.18)$. The highest correlation is found in the "violence" subscale score on the IPVAS-R with the Revised Conflict Tactic Scale (CTS-2) subscale score, namely "physical assault" ( $\mathrm{r}=0.39)$, and the "abuse" and "control" subscales correlate with subscale score "psychological aggression" with $\mathrm{r}=0.43$ and $r=0.27$ (Fincham et al., 2008: 265266).

Parental attachment scores on the IPPA scale have a moderate to a strong relationship with the "family self-concept" and "social self-concept" subscale scores on the TSCS scale, which have correlation coefficients of 0.78 and 0.46 . In addition, parental attachment scores also have a relatively strong relationship with most of the subscales on the FES scale, with correlation coefficients ranging from 0.36- 
0.56. There is a moderate to a strong relationship between parental attachment and most subscales in the Family and Peer Utilization. This subscale has a correlation coefficient range of 0.54-0.62 (Greenberg \& Armsden, 1987: 438-439; 2009: 2).

A reliable instrument is an instrument that can produce accurate scores with minor measurement errors (Azwar, 2017: 111). Reliability refers to the reliability or consistency of the measurement results, which means how high the accuracy of the measurement is. Reliability on the attachment scale to the mother has a very high reliability coefficient with a reliability coefficient of 0.87 (Greenberg \& Armsden, 2009: 2). The scale of violence in romantic relationships has high reliability with a reliability coefficient value of 0.76 . Reliability is calculated based on the try out using the Cronbach's Alpha formula with the help of SPSS for windows.

Data Analysis

The data obtained is then analyzed descriptively and categorized based on the Azwar (2017: 149) formula. The categorization norm can be seen in Table 1. The results of the prerequisite test show that the data obtained are not normally distributed. In addition, the random requirement was also not met because it used accidental sampling, so nonparametric correlation test analysis was used to test the hypothesis.

Table 1. Categorization Norm

\begin{tabular}{lll}
\hline Score Interval & Criteria & $\begin{array}{c}\text { max } \\
\text { stan } \\
\text { don }\end{array}$ \\
\hline$\mu+1,0 \sigma \leq X$ & High & Tab \\
$\mu-1,0 \sigma \leq X<\mu+1,0 \sigma$ & Moderate & \\
$X<\mu-1,0 \sigma$ & Low & \\
\hline
\end{tabular}

\section{Finding}

The data of this study were obtained from 408 subjects with the following details:

Table 1. Research Subject Data Based on Age

\begin{tabular}{lll}
\hline Age & n & $\mathbf{\%}$ \\
\hline 18 & 20 & $4,9 \%$ \\
19 & 54 & $13,2 \%$ \\
20 & 74 & $18,1 \%$ \\
21 & 135 & $33,1 \%$ \\
22 & 125 & $30,6 \%$ \\
\hline Total & $\mathbf{4 0 8}$ & $\mathbf{1 0 0} \%$ \\
\hline
\end{tabular}

Table 2. Research Subject Data Based on Length of Establishing Romantic Relationships

\begin{tabular}{lll}
\hline Length & $\mathbf{n}$ & $\mathbf{\%}$ \\
\hline$\leq 6$ months & 70 & $17 \%$ \\
$6-12$ months & 64 & $16 \%$ \\
$12-24$ months & 85 & $21 \%$ \\
$24-36$ months & 57 & $14 \%$ \\
$\geq 36$ months & 132 & $32 \%$ \\
\hline Total & $\mathbf{4 0 8}$ & $\mathbf{1 0 0} \%$ \\
\hline
\end{tabular}

Based on Table 2, most subjects were 21 years old, namely 135 people or $33.1 \%$. In addition, from Table 3 . it can also be concluded that most of the subjects have been in a romantic relationship for more than 36 months, which is $32 \%$.

The data that has been collected is then categorized by calculating the mean, maximum score, minimum score, and standard deviation. The calculation is done manually, and in detail can be seen in Table 4. 
Table 3. Description of Violence Variable Data in Romantic Relationships

\begin{tabular}{ll}
\hline Mean & 42 \\
Standard Deviation & 9,33 \\
Minimum & 14 \\
Maximum & 70 \\
\hline
\end{tabular}

Table 4. shows that the maximum score obtained is 70 , while the minimum score obtained is 14 . The hypothetical average obtained is $=42$, with a standard deviation of 9.33 . Based on the mean and standard deviation obtained, the categorization of violence in romantic relationships is presented in Table 5 . Furthermore, the distribution of the frequency of categorization of violence in romantic relationships is presented in a diagram as shown in Figure 1.

Table 4. Results of Categorization of Violence Variables in Romantic Relationships

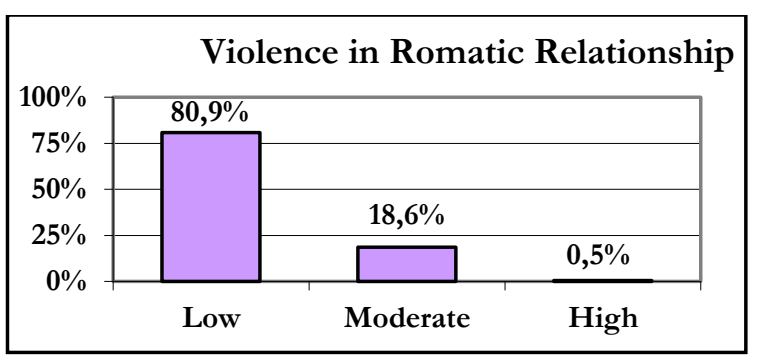

Figure 1. Frequency Categorization Distribution of Violence in Romantic Relationships

Based on Table 5. and Figure 1., it is known that the low level of violence in romantic relationships is $80.9 \%$, the medium level is $18.6 \%$, and the high level is $0.5 \%$. Therefore, it can be concluded that most of the subjects in this study tend to commit violence in romantic relationships in the low category.

Furthermore, for safe attachment to the mother, the same thing was done in determining the categorization. However, for this variable, categorization is carried out on the total score of each of its

\begin{tabular}{|c|c|c|c|}
\hline Category & Range & Freq. & Peregnfetgigent dimensions, namely the \\
\hline High & $51,33 \leq X$ & 2 & $0,5 \%$ dimensions of trust, communication, and \\
\hline Moderate & $32,67 \leq X<51,33$ & 76 & 18, aljienation. Details of the calculation of the \\
\hline Low & $X<32,67$ & 330 & $\begin{array}{l}\text { categonzation formula can be seen in } \\
80 \text {, 99able } 6 \text {. }\end{array}$ \\
\hline Total & & 408 & $100 \%$ \\
\hline
\end{tabular}

Table 5. Description of Safe Attachment Variable Data with Mother

\begin{tabular}{llll}
\hline & Trust & Communication & Alieniation \\
\hline Mean & 42 & 27 & 18 \\
Standard Deviation & 9,33 & 6 & 4 \\
Minimum & 14 & 45 & 30 \\
Maximum & 70 & 9 & 6 \\
\hline
\end{tabular}

Table 6. shows that on the scale of safe attachment with mother, maximum and minimum scores for each dimension are obtained, namely the dimensions of trust of 50 and 10, dimensions of communication of 45 and 9 , and dimensions of alienation of 30 and 6 . obtained for the dimensions of trust, communication, and alienation are 30,27, and 18 with standard deviations of $6.67,6$, and 4. Based on the mean and standard deviation obtained, the categorization of each dimension is presented in Table 7. 


\section{Relationship Between Child-Mother Secure Attachment Style and Violence Muhammad \& Ayriza}

Table 6. Categorization of Safe Attachment Dimensions with Mother

\begin{tabular}{llll}
\hline \multicolumn{2}{l}{ Score Interval } & & \\
\hline Category & Trust & Communication & Alieniation \\
\hline High & $36,67 \leq \mathrm{X}$ & $33 \leq \mathrm{X}$ & $22 \leq \mathrm{X}$ \\
Moderate & $23,33 \leq \mathrm{X}<36,67$ & $21 \leq \mathrm{X}<33$ & $14 \leq \mathrm{X}<22$ \\
Low & $\mathrm{X}<23,33$ & $\mathrm{X}<21$ & $\mathrm{X}<14$ \\
\hline
\end{tabular}

The secure attachment style or "high security" classification seen from the total value of the dimension of trust or communication dimension is in the medium or high category. The total value of the alienation dimension is in the low or medium category. Based on these criteria, the distribution of the attachment style with the mother is obtained as presented in Table 8. Furthermore, the frequency distribution of the categorization of safe attachment with the mother is presented in a diagram as shown in Figure 2.

Table 8. Categorization of Attachment Variables with Mother

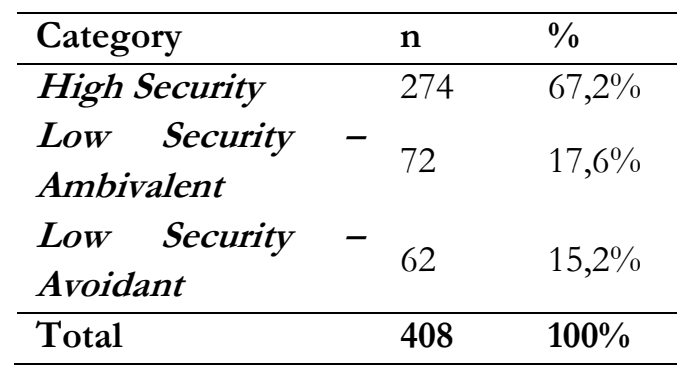

Attachment Style with Mother

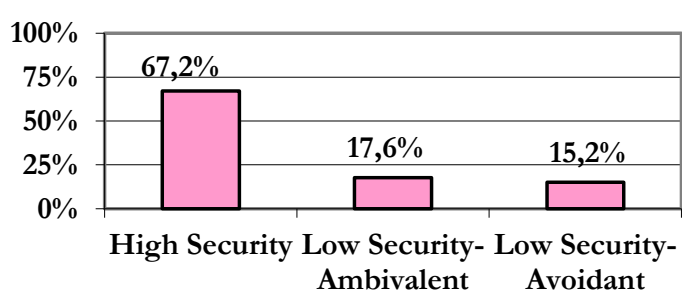

Figure 2. Frequency Distribution of Attachment Categorization with Mother
Based on Table 8 and Figure 2, it is known that the subjects who have a secure attachment style with their mother as many as 274 people or $67.2 \%$, insecureambivalent attachment style as many as 72 people or $17.6 \%$, and insecure-avoidance attachment style as many as 62 people or by $15.2 \%$. It can be concluded that most of the subjects in this study have a secure attachment style with their mother.

After that, the hypothesis was tested using Spearman's Rho nonparametric correlation test analysis with the help of the SPSS program. If Sig. $<0.05$, it can be concluded that there is a significant correlation between the variables studied. If Sig.> 0.05, then there is no significant correlation between the variables studied. The results of hypothesis testing can be seen in Table 9 .

Table 9. Hypothesis Test Results

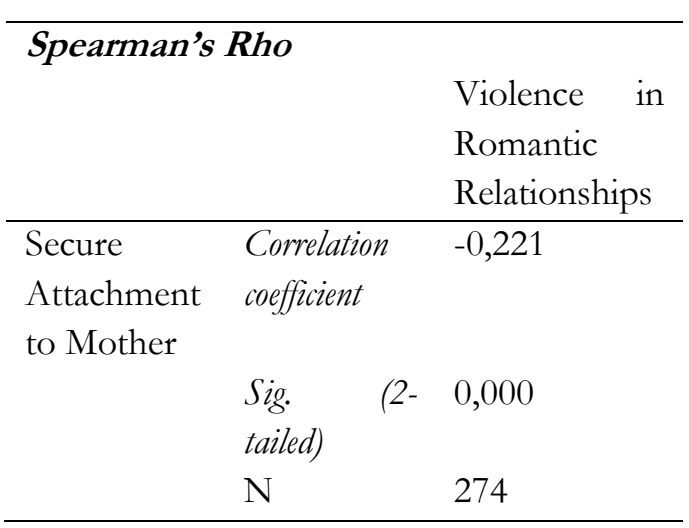

Based on Table 9., it is known that the correlation coefficient value is $r=-.221$ 
with Sig. (2-tailed) of $=.000(\mathrm{p}<0.01)$. This shows a significant negative relationship between mother-child secure attachment style and violence in romantic relationships. The higher the secure attachment style between the child and mother, the lower the violence in romantic relationships.

\section{Discussion}

Data analysis shows a significant negative relationship between childmother secure attachment style and violence in romantic relationships. This means that the higher the secure attachment style between children and mothers, the lower the violence in romantic relationships. When an individual has a secure attachment, they can regulate emotions, manage interpersonal relationships, and deal with conflicts or difficult situations that befall him well. Individuals need these things, especially teenagers, to establish good relationships with their partners to avoid violence in romantic relationships.

This study also has results that align with the research conducted by Dutton et al. (1994), in which secure attachment style has a negative relationship with partner violence (Dutton et al., 1994: 1376). In addition, the research of Dutton et al. (1994: 1376) also found a negative relationship between secure attachment and emotional reactivity in the form of anger and jealousy. Based on Rohmah \& Legowo (2014: 4) research results, anger and jealousy are among the factors that cause violence in romantic relationships. Jealousy can also make individuals tend to dominate and restrain their partners (Rohmah \& Legowo 2014: 4).

According to Dutton et al. (1994: 1369), individuals with secure attachments have positive models of self and others who make themselves feel confident and comfortable with the intimacy in their romantic relationships. Individuals who have a secure attachment style believe that they deserve to be loved, cared for, and cared for, while others are seen as trustworthy and always there (Pace, San Martini, \& Zavattini, 2011: 83). A positive view of themselves makes them feel confident about their ability to handle their partner's needs without feeling overwhelmed (Mikulincer \& Shaver, 2012: 265). A positive view of others makes it easy for them to interpret their partner as someone who deserves sympathy and support (Mikulincer \& Shaver, 2012: 265). This is also in line with research by Mayseless \& Scharf (2007). According to Mayseless \& Scharf (2007: 26), adolescents with secure attachments have high levels of trust and high satisfaction and intimacy in romantic relationships.

The subjects in this study were late teens, the majority of whom were 21 years old, so emotionally, cognitively, and socially had reached maturity following their developmental characteristics. One form of emotional maturity is the ability to regulate emotions well. Emotion regulation can assess, manage, reveal, and deal with emotions appropriately so that unwanted actions do not occur (Gross, 2014 in Megawati, Anwar, \& Masturah 2019: 216). Individuals with good emotion regulation can control their emotions and express their emotions appropriately when facing conflicts with their romantic relationship partners. Good emotional regulation can also reduce aggression so that when dealing with conflicts with partners, problem-solving is taken not to use violence.

The statement above is according to research conducted by Megawati, Anwar, \& Masturah (2019), which states a relationship between emotional regulation and violence in romantic relationships among university students. Individuals with good emotional regulation ability can control their emotions and direct themselves according to their goals so that aggression does not occur (Shorey, 
McNulty, Moore, \& Stuart, 2015 in Megawati, Anwar, \& Masturah, 2019: 217). In addition, according to the Ministry of Women's Empowerment and Child Protection (2018), one of the factors that can cause violence in romantic relationships is the lack of emotional control during fights. The lack of emotional control in this individual is undoubtedly related to the ability to regulate emotions. This is also reinforced by research by Larasati \& Desiningrum (2017). The study results revealed a positive relationship between emotional regulation and attachment style with the mother, especially the secure attachment style. This means that the higher the emotional regulation possessed, the higher the secure attachment to the mother.

In addition, according to Mikulincer \& Shaver (2012: 263), individuals with secure attachments also tend to have more positive beliefs about conflict and conflict resolution. This is done by maintaining open communication, negotiating during the conflict, and relying on effective conflict resolution such as compromise and integration of needs and behaviours between partners. They use interpersonal conflict as an opportunity to increase harmony, satisfaction, and stability in relationships. In addition, they feel comfortable with intimacy and interdependence, which helps in responding positively when partners ask for help and express feelings of need (Mikulincer \& Shaver, 2012: 265).

The correlation coefficient obtained in this study is -0.221 , which means that violence in romantic relationships and secure attachment with mothers has a low correlation value. This may occur possibly because of other variables that affect violence in romantic relationships. Some of these possibilities are social learning processes and outcomes, childhood abuse, attitudes and beliefs, relationship history and experiences, low levels of education, drug use, and exposure to violent media (Wolfe, Scott, \& Crooks, 2005: 394-399). It is hoped that through this research, parents can apply a secure attachment style as a form of good parenting to children in order to prevent violence when establishing romantic relationships.

\section{Conclusion}

Based on the results of research and discussions carried out, it can be concluded that there is a significant negative relationship between motherchild secure attachment style and violence in romantic relationships. This means that the higher the secure attachment that the child has with the mother, the lower the violent behaviour in romantic relationships during adolescence.

\section{Suggestion}

Based on the research that has been done, the following are some suggestions given by researchers for related parties, namely:

\section{Parents or Caregivers}

It is hoped that parents, especially mothers, can pay more attention and realize the importance of good parenting. Good parenting cultivates a secure attachment style between children and parents to create trust, good communication and avoid feeling alienated. Parents with a secure attachment style will be responsive to the needs and desires of children from birth which form the essential trust so that the child's perception and perspective on the world is a safe place. Parenting based on a secure attachment style impacts the psychological development of children, especially in social relationships. It is also hoped that with this research, parents can instil awareness that parenting given from birth will have a lifelong impact on 
children because of the nature of continuous attachment. In addition, with this research, it is hoped that parents can pay more attention to issues and signs of violence in romantic relationships in their children.

\section{Teenagers}

It is hoped that teenagers will be more aware of the issues and signs of violence in romantic relationships and what underlies this. In addition, it is hoped that adolescents can realize what attachment style they and their romantic partners have so that by realizing as early as possible, adolescents can anticipate the occurrence of violence in romantic relationships and create healthy romantic relationships.

\section{Practitioners/Stakeholders/}

Government

Based on the results obtained in this study, it is hoped that it can be an alternative consideration in intervening in violence cases for practitioners. In addition, preventive counselling on good parenting and attachment is also needed to know and understand what attachment is and its effect on children. Counselling about acts of violence in romantic relationships also needs to be done so that preventive efforts can be carried out immediately. Perpetrators of counselling may be carried out by the Ministry of Women's Empowerment and Child Protection, the BKKBN, and agencies or communities related to parenting and protection from acts of violence.

\section{Further research}

For further research, it is expected to spread the scale with a broader subject and use a random sampling technique so that the possibility of data distribution will be more evenly distributed and the data can be normally distributed. If the data distribution is evenly distributed and the data is normally distributed, then parametric analysis can be used so that the results obtained can be generalized. In addition, it is hoped that further research can develop research on relationships or the influence of other variables that may be stronger on violence in romantic relationships. Other variables in question include childhood violence or abuse, attitudes and beliefs about aggressive behaviour, peer social support, relationship history and experiences, drug and alcohol use, education level, and economic needs.

\section{References}

Ardi, Z., Ibrahim, Y., \& Said, A. (2012). Capaian tugas perkembangan sosial siswa dengan kelompok teman sebaya dan implikasinya terhadap program pelayanan bimbingan dan konseling. Konselor, 1(2). https://doi.org/10.24036/0201212 522-0-00

Armsden, G. C., \& Greenberg, M. T. (1987). The inventory of parent and peer attachment: individual differences and their relationship to psychological well-being in adolescence. Journal of Youth and Adolescence, 16(5), 427-454. https://doi.org/10.1007/bf022029 39

Armsden, G., \& Greenberg, M. T. (2009). Inventory of parent and peer attachment- revised. College of Health and Human Development, 1-12

Azwar, S. (2017).Penyusunan skala psikologi ( $2^{\text {nd }}$ ed.). Yogyakarta: Pustaka Pelajar

Azwar, S.(2018).Metode penelitian psikologi $\left(2^{\text {nd }}\right.$ ed.). Yogyakarta: Pustaka Pelajar

Cooper, M. L., Shaver, P. R., \& Collins, N. L. (1998). Attachment styles, emotion regulation, and adjustment in adolescence. Journal of Personality 
and Social Psychology, 74(5), 13801397.

https://doi.org/10.1037/0022-

3514.74.5.1380

Desiningrum, D. R. (2018). Hubungan secure attachment dengan ibu dan kecenderungan berperilaku agresi pada siswa SMA N 2 Ungaran. Jurnal Empati, 7(3), 80-89

Dutton, D. G., Saunders, K., Starzomski, A., \& Bartholomew, K. (1994). Intimacy anger and insecure attachment as precursors of abuse in intimate relationships. Journal of Applied Social Psychology, 24(15), 1367-1386.

https://doi.org/10.1111/j.1559-

1816.1994.tb01554.x

Erdianto, Kristian. 7 Maret 2016.Angka Kekerasan dalam Pacaran Tinggi, tetapi UU Belum Melindungi. KOMPAS.com. Diakses tanggal 27 Februari dari 2018https://nasional.kompas.com/ $\mathrm{read} / 2016 / 03 / 08 / 07513391 /$ Angk a.Kekerasan.dalam.Pacaran.Tinggi.t etapi.UU.Belum.Melindungi.

Fadhilah, E. A., Arjawa, I. G. P. B. S., \& Mahadewi, N. M. A. S. (2016). Perilaku posesif dalam gaya berpacaran di kalangan remaja Kota Denpasar. Fakultas Ilmu Sosial Dan Imu Politik. Universitas Udayana, 1-12

Fincham, F. D., Cui, M., Braithwaite, S., \& Pasley, K. (2008). Attitudes toward intimate partner violence in dating relationships. Psychological Assesment, 20(3), 260-269. https://doi.org/10.1037/10403590.20.3.260

Hazan, C., \& Shaver, P. R. (1994). Attachment as an organizational framework for research on close relationships. Close Relationships: Key Readings, pp. 186-214. https://doi.org/10.4324/97802033 11851
Kementrian Pemberdayaan Perempuan dan Perlindungan Anak. 20 Maret 2018. Diakses tanggal 16 Desember 2019 dari https://www.kemenpppa.go.id/ind ex.php/page/read/31/1669/waspa da-bahaya-kekerasan-dalam-pacaran

Larasati, N. I., \& Desiningrum, D. R. (2017). Hubungan antara kelekatan aman dengan ibu dan regulasi emosi siswa kelas X SMA Negeri 3 Salatiga. Empati, 7(3), 127-133

Mayseless, O. (1991). Adult Adult attachment patterns and courtship violence. Family Relations, 40(1), 2128.

https://doi.org/10.2307/585654

Mayseless, O., \& Scharf, M. (2007). Adolescents attachment representations and their capacity for intimacy in close relationships. Journal of Research on Adolescence, 17(1), 23-50

Megawati, P., Anwar, Z., \& Masturah, A. N. (2019). Hubungan regulasi emosi dengan perilaku kekerasan dalam berpacaran pada mahasiswa. Cognicia, 7(2), 214-227. Retrieved from

http://ejournal.umm.ac.id/index.p $\mathrm{hp} /$ cognicia

Mikulincer, M., \& Shaver, P. R. (2012). Adult attachment orientations and relationship processes. Journal of Family Theory \& Review, 4(4), 259274.

https://doi.org/10.1111/j.1756-

2589.2012.00142.x

Pace, C. S., San Martini, P., \& Zavattini, G. C. (2011). The factor structure of the inventory of parent and peer attachment (IPPA): A survey of italian adolescents. Personality and Individual Differences, 51(2), 83-88. https://doi.org/10.1016/j.paid.201 1.03 .006 
Putro, K. Z. (2017). Memahami ciri dan tugas perkembangan masa remaja. Aplikasia: Jurnal Aplikasi Ilmu-Ilmu Agama, 17(1), 25-32. Retrieved from ejournal.uin-

suka.ac.id/pusat/aplikasi

Rohmah, S., \& Legowo, M. (2014). Motif kekerasan dalam relasi pacaran di kalangan remaja muslim. Paradigma, 2(1), 1-9.

Sanjaya, E. (2016). Hubungan antara gaya kelekatan dengan kekerasan dalam relasi romantis pada remaja. Skripsi. Universitas Sanata Dharma.

Santrock, J. W. (2011). Life-span development perkembangan masa-hidup jilid I (13th ed.). Jakarta: Erlangga

Santrock, J. W. (2012). Life-span development perkembangan masa-bidup jilid II (13th ed.). Jakarta: Erlangga

Smith, B. A., Thompson, S., Tomaka, J., \& Buchanan, A. C. (2005). Development of the intimate partner violence attitude scales (IPVAS) with a predominantly mexican american college sample. Hispanic Journal of Behavioral Sciences, 27(4), 442-454. https://doi.org/10.1177/07399863 05281233

Trifiani, N. R., \& Margaretha. (2012). Pengaruh gaya kelekatan romantis dewasa ( adult romantic attachment style ) terhadap kecenderungan untuk melakukan kekerasan dalam pacaran. Jurnal Psikologi Kepribadian Dan Sosial, 1(02), 74-83

Wolfe, D. A., \& Feiring, C. (2000). Dating violence through the lens of adolescent romantic relationships. Child Maltreatment, 5(4), 360-363

Wolfe, D. A., Scott, K. L., \& Crooks, C. V. (2005). Abuse and violence in adolescent girls' dating relationships. In Handbook of Behavioral and Emotional Problems in Girls (pp. 381-
414). https://doi.org/10.1007/0306-48674-1_13

Yuliani, A., \& Fitria, N. (2017). Peran preoccupied attachment style terhadap kecenderungan mengalami stockholm syndrome pada perempuan dewasa awal. Psympathic: Jurnal Ilmiah Psikologi, 4(2), 275-288. https://doi.org/10.15575/psy.v4i2. 1341 